\title{
Microbial Quality and Safety of Raw Vegetables of Fiche Town, Oromia, Ethiopia
}

\author{
Birhanu Degaga, ${ }^{1}$ Israel Sebsibe ${ }^{D},{ }^{2}$ Tolosa Belete,${ }^{3}$ and Adugna Asmamaw ${ }^{4}$ \\ ${ }^{1}$ Salale University, Applied Microbiology, Fiche, Ethiopia \\ ${ }^{2}$ Salale University, Ecology and Systematic Zoology, Fiche, Ethiopia \\ ${ }^{3}$ Salale University, Environmental Sciences, Fiche, Ethiopia \\ ${ }^{4}$ Salale University, Botany, Fiche, Ethiopia \\ Correspondence should be addressed to Israel Sebsibe; israelmaru4@gmail.com
}

Received 22 December 2021; Accepted 27 January 2022; Published 17 February 2022

Academic Editor: Arun S. Kharat

Copyright (c) 2022 Birhanu Degaga et al. This is an open access article distributed under the Creative Commons Attribution License, which permits unrestricted use, distribution, and reproduction in any medium, provided the original work is properly cited.

\begin{abstract}
Vegetables contain vital ingredients such as minerals, phytochemicals, vitamins, and fibers, which play significant roles in human health. Consumption of fresh vegetables causes human infections and outbreaks while serving as a reservoir of several pathogens. The study evaluated the microbiological quality of raw vegetables consumed in and around Fiche town, Central Ethiopia. For the experimental study, a total of 100 samples of 5 different raw vegetables from two local markets were selected based on their commonalities for overall microbial quality in terms of aerobic mesophilic count, total coliform count, Enterobacteriaceae count, Staphylococci count, and yeast and mold levels. The highest count was aerobic mesophilic bacteria ( $5.7 \log \mathrm{CFU} / \mathrm{g}$ ) followed by Enterobacteriaceae $(4.7 \log \mathrm{CFU} / \mathrm{g})$, while yeasts and molds count the least. The maximal count for aerobic mesophilic bacteria was enumerated in cabbage ( $6.4 \mathrm{log} \mathrm{CFU} / \mathrm{g})$ while the minimum was in green pepper samples (4.7 $\log \mathrm{CFU} / \mathrm{g}$ ). Among 100 vegetable samples analyzed, $11 \%$ were contaminated by $S$. aureus which is highly prevalent in cabbage (20\%), followed by lettuce (15\%). In the present study, $15.0 \%$ of vegetable samples were positive for Salmonella and detected in all vegetable types.
\end{abstract}

\section{Introduction}

The consumption of vegetables has enormously increased because of their nutritive values in daily dietary intake. Vegetables are important sources of many minerals and vitamins too. The Australian dietary guidelines recommend that an adult human should eat at least five kinds of vegetables every day [1]. Demand for the consumption of vegetables is on the rise since the fresh production of vegetables provides biologically active compounds such as phenolics, anthocyanins, and antioxidants that aid in better health [2] and have a prominent role to play in the prevention of heart diseases, cancer, diabetes, obesity, and micronutrient deficiencies (zinc, iron, etc.) mainly in developing countries [3]. In addition, there are broad product development opportunities because vegetables are a handy snack food and are easily carried. Currently, farmers and local public markets are the chief retailers of raw vegetables [4].

But, the consumption of fresh vegetables causes human infections and outbreaks while serving as a reservoir of several pathogens [5-8] Moreover, Halablab et al. [9] indicated that there is increased consumer demand for fresh, natural, and organically cultivated products, devoid of microorganisms. This necessitates to handle the product with care before it reaches the consumers. Enteric pathogens such as Escherichia coli and Salmonella are among the greatest concerns during food-related outbreaks. Several cases of typhoid fever outbreaks have been associated with eating contaminated vegetables grown in or fertilized with contaminated soil or sewage [4]. It has been indicated that various bacterial pathogens, including Salmonella, Shigella, 
Campylobacter, E. coli O157:H7, Listeria monocytogenes, and Staphylococcus aureus, are the contaminants for most vegetables $[8,10-13]$.

The presence of aerobic mesophilic bacteria found in food is one of the microbiological indicators for food quality [14]. While indicating the existence of favorable conditions for the multiplication, coliform bacteria have long been used as indicator organisms that reflect the general microbiological condition of foods and water. It is a potential public health risk $[15,16]$. Staphylococcus aureus induces food poisoning through its enterotoxins that are frequently responsible for food-borne illness outbreaks [4].

In different parts of Ethiopia, vegetables are being widely cultivated traditionally by rural farmers for several decades. The farmers provide vegetables to the local market. But the absence of well-ventilated storage, lack of pre and postharvesting practice at marketplaces, and inappropriate transportation techniques have been major constraints of market quality [17]. In these conditions, potential physical damages and contamination of vegetables with animals and human feces become undoubtedly possible before consumption [10]. Vegetables can also be contaminated during transportation, selling, storage, and after purchase by consumers [14]. Fresh vegetables can be contaminated at any point in the production and market chain, posing a potential food safety problem because they are likely to be consumed raw $[18,19]$. In addition, prevention mechanism failure may lead to a large economic loss following an outbreak [20]. Thus, it is rational to assess the safety of these vegetables in consideration to the consumers' safety.

\section{Materials and Methods}

2.1. Study Design, Study Population, and Data Source. Based on cross-sectional study design, 120 vegetable cultivators and sellers were selected on sites from which vegetable samples were also purchased to get reliable information. The samples were collected from Komando and Fitche sites. These different sites were selected to represent the whole vegetables sold in Fitche town. The study periods were covered from January 2020 to October 2020. Primary data were generated from the survey, and standard laboratory experiments were used to analyze vegetable samples collected from markets and shops in Fitche town.

2.2. Data Collection. Vegetable cultivators and sellers were surveyed using a systematic random sampling method. A survey was conducted using structured questionnaires from randomly selected vegetable cultivators, sellers, and consumers from which the vegetable samples were purchased.

2.3. Sample Collection. A total of 100 fresh vegetable samples were collected from two different sites of Fiche town. Taking samples from different places allowed products that are commonly available to consumers to be sampled which makes the results of this study more representative. Based on their commonalities, tomato (Solanum copersicum), cabbage (Brassica oleracea), green pepper (Capsicum annuum), lettuce (Lactuca sativa), and carrot (Daucus carota) were selected to be tested. The samples comprised of 20 each of selected commodities and were collected using sterile plastic bags. The samples were sent for analysis within 6 hours of the collection.

2.4. Sample Preparation. Packaging bags were aseptically opened using a sterile stainless steel knife, and $25 \mathrm{~g}$ portions were weighted and shaken in $225 \mathrm{ml}$ of sterile $0.1 \%(\mathrm{w} / \mathrm{v})$ buffered peptone water for three minutes letting the samples homogenized [21]. Total coliform count, aerobic mesophilic count, Enterobacteriaceae count, Staphylococci count, yeast, and mold were enumerated from the homogenate of the samples prepared.

2.5. Total Aerobic Mesophilic Count. The total viable aerobic mesophilic count was determined by plate count using the standard plate count agar (PCA) medium. Serial dilutions of the samples were made in $0.1 \%$ buffered peptone water; $0.1 \mathrm{ml}$ from each dilution $\left(10^{-1}\right.$ to $\left.10^{-7}\right)$ was pipetted and spread plated on a standard presolidified plate count agar medium and incubated at $32^{\circ} \mathrm{C}$ for 72 hours. After incubation, plates with colonies from 30 to 300 were counted [21].

2.6. Total Coliform Count. A $0.1 \mathrm{ml}$ of homogenate from $10^{-1}-10^{-5}$ dilution was pipetted and spread on violet red bile agar (VRBA). Total coliforms of all vegetable samples were counted on VRBA after incubating plates at $35^{\circ} \mathrm{C}$ for $18-24$ hours. Red to pink colonies, surrounded by precipitated bile, were counted as coliforms [22].

2.7. Enterobacteriaceae Count. To count the members of Enterobacteriaceae, $0.1 \mathrm{ml}$ of $10^{-1}-10^{-5}$ serial dilution of the vegetable samples were spread plated on MacConkey agar and incubated at $32^{\circ} \mathrm{C}$ for 24 hours. All purple colonies were counted as members of Enterobacteriaceae [22].

2.8. Staphylococci Count. For Staphylococci, the count was determined by mannitol salt agar (MSA). MSA was surface plated with $0.1 \mathrm{ml}$ of the homogenate from $10^{-1}-10^{-5}$ and incubated at $32^{\circ} \mathrm{C}$ for 36 hours. Then, golden yellow color colonies were aseptically picked and purified. A coagulase test was conducted to identify Staphylococcus aureus [23].

2.9. Yeast and Mold Counts. The count of yeasts and molds was determined by direct plate count using potato dextrose agar (PDA) supplemented with $0.1 \mathrm{~g}$ chloramphenicol. About $0.1 \mathrm{ml}$ of the homogenate from $10^{-1}$ dilution was spread plated on PDA that contains chloramphenicol. The plates were incubated at $25-28^{\circ} \mathrm{C}$ for 3-5 days. After incubation, yeasts and molds were counted separately. Smooth (nonhairy) colonies without an extension at the periphery (margin) were considered and counted as yeasts. Hairy colonies with extension at the periphery were counted as molds [22]. 


\section{Results}

3.1. Sociodemographic Information. A total of 120 cultivars, sellers, retailers, and consumers were interviewed in which majority (90\%) were from urban areas. A significant number $(60 \%)$ of the respondents were consumers. Regarding educational status, majority (65\%) of them were beyond secondary education. Regarding religion status, 93.3\%, 5.8\%, and $0.8 \%$ of the respondents were Orthodox, Protestant, and Muslim, respectively (Table 1 ).

3.2. General Sanitary Conditions. Regarding diseases caused by consuming contaminated vegetables, $85 \%$ of the respondents have such information. Majority (65\%) had health problems due to the consumption of contaminated vegetables. Concerning how fresh vegetables reach the market, 45\%, 25\%, 20\%, and 10\% were transported using a car, back of humans, cart, and horse/donkey, respectively. Majority (53\%) of vegetables were transported to the market using sac. Regarding the arrangement of vegetables in the market, 56\% were well organized without close contact. Moreover, $57.5 \%$ of vegetable sellers have used shade to protect vegetables from physical damage due to strong sunlight and others (Table 2). Regarding time, taking fresh vegetables left with sellers/retailers, on the one hand, $40 \%$ of them responded in about 3 days before totally sold to the consumer. On the other hand, $50 \%$ of them did not add food-grade chemicals such as vinegar to raw-consumed vegetables. Moreover, only $45 \%$ of the consumers used a refrigerator to store fresh vegetables (Table 2).

3.3. Consumption Habit. Regarding the consumption habit of consumers, majority preferred to consume vegetables as raw, specifically green pepper, carrot, and lettuce. However, tomato and cabbage were preferred to be consumed after cooking (Figure 1).

3.4. Microbiological Count of Raw Vegetables. Table 3 shows that the highest count was aerobic mesophilic bacteria (5.7log CFU/g) followed by Enterobacteriaceae (4.7 log CFU/g). But, the least was yeasts and mold count (2.3 log $\mathrm{CFU} / \mathrm{g}$ and $2.0 \log \mathrm{CFU} / \mathrm{g}$ ), respectively. The maximal count for aerobic mesophilic bacteria was enumerated in cabbage (6.4 log CFU/g) while the minimum was in green pepper samples (4.7 log CFU/g). Similarly, the maximum Enterobacteriaceae and Staphylococci count were recorded in cabbage (5.7 log CFU/g and $\log 5.3 \mathrm{CFU} / \mathrm{g}$ ) while the minimum was in carrot samples (4.2 log CFU/g and $3.3 \mathrm{log}$ $\mathrm{CFU} / \mathrm{g}$ ), respectively (Table 3 ). There was a statistically significant difference $(P<0.05)$ among the mean counts of all the microbial groups in the vegetable samples.

The aerobic mesophilic count of cabbage and carrot in both Komando and Fitche sites was higher ( $>6 \log \mathrm{CFU} / \mathrm{g}$ ). Similarly, the Enterobacteriaceae count of cabbage and lettuce is higher in both sites ( $>5 \log \mathrm{CFU} / \mathrm{g})$. The Staphylococci count was the lowest in tomato $(<3 \log \mathrm{CFU} / \mathrm{g})$ in both sites (Figures 2 and 3).
Accordingly, the aerobic mesophilic count of tomato samples was between 5 and $6.9 \mathrm{log} \mathrm{CFU} / \mathrm{g}$. Similarly, all (100\%) of cabbage samples had Enterobacteriaceae counts between 5 and $6.9 \log$ CFU/g. Over $40 \%$ of vegetable samples had coliforms $\geq 4 \log \mathrm{CFU} / \mathrm{g}$. However, in all the vegetable samples, Staphylococci count was between 2 and $2.9 \log$ CFU/g. The yeasts and molds were mostly between 1 and 2.9 log CFU/g range in which some were below the detectable level (Table 4).

3.5. Frequency of Isolation of Pathogens. Among 100 vegetable samples analyzed, $11 \%$ were contaminated by S. aureus. S. aureus isolates were highly prevalent in cabbage (20\%) followed by lettuce (15\%). On the contrary, only $1(5 \%)$ $S$. aureus was isolated from green pepper samples. In carrot samples, S. aureus was not detected (Table 5). The present study showed that $15.0 \%$ of vegetable samples were positive for Salmonella and could be detected in all vegetable types (Table 5). A high prevalence (25\%) of Salmonella was isolated from lettuce samples followed by tomato and cabbage (20\% from each sample). The least (5\%) were detected from each green pepper and carrot sample (Table 5). Shigella was not detected in any of the vegetable types.

\section{Discussion}

Microorganisms such as bacteria, fungi, and viruses are ubiquitous that may reside on vegetables to survive [24], suggesting the sanitary and hygienic quality of the postharvesting practice, water, transportation, storage, and processing of the production [25-27]. Consumption of raw or partly cooked vegetables is a common practice among the population of the study sites. The present assessment of vegetable samples analyzed for microbiological quality indicated high counts including aerobic mesophilic bacteria, Enterobacteriaceae, coliforms, and Staphylococci. However, the yeast and mold counts showed relatively low counts.

The present study showed that AMB count values were between $3.4 \mathrm{log} \mathrm{CFU} / \mathrm{g}$ (green pepper) and $7.4 \mathrm{log} \mathrm{CFU} / \mathrm{g}$ (cabbage). On the contrary, Khiyami et al. [28] reported that $\mathrm{AMB}$ counts were between $5 \log \mathrm{CFU} / \mathrm{g}$ and $5.7 \log \mathrm{CFU} / \mathrm{g}$. Other vegetables such as leaf lettuces, spinach, and carrot were also reportedly positive $(3.6 \log 10 \mathrm{CFU} / \mathrm{g}$ ) for $\mathrm{AMB}$ [20]. Mritunjay and Kumar [29] reported that most of these microorganisms managed to grow in the storage temperature. Therefore, high counts of AMB are an indication of exposure to contaminants because of the existence of $\mathrm{fa}$ vorable conditions [30]. Furthermore, domesticated food animals, flies, and rodents might be a source of contamination through direct contact at vegetable farms [31]. Foods containing aerobic mesophilic bacteria are considered as good (<4 log10 CFU/g), average (4.0-6.7log10 CFU/g), poor (6.7-7.7 $\log 10 \mathrm{CFU} / \mathrm{g})$, and spoiled food $(>7.7 \log 10 \mathrm{CFU} / \mathrm{g})$ [32]. Based on these criteria, only $10 \%$ of green peppers were regarded as good, whereas tomato, carrot, and lettuce were average. But $15 \%$ of cabbage samples can be rated as poor of microbial quality regarding aerobic mesophilic bacteria. The samples with the highest Enterobacteriaceae counts were 
TABle 1: Sociodemographic characteristics of vegetable cultivars, sellers, retailers, and consumers in Fitche town, Central Ethiopia, 2020.

\begin{tabular}{lcc}
\hline Characteristics & Frequency & Percent \\
\hline Address & & \\
Urban & 108 & 90 \\
Rural & 12 & 10 \\
Academic status & 0 & 0 \\
Illiterate & 42 & 35 \\
Elementary education & 78 \\
Secondary education and above & & 65 \\
Religion & 1 & 0.8 \\
Muslim & 112 & 93.3 \\
Orthodox & 7 \\
Protestant & 0 & 5.8 \\
Others & & 0 \\
Respondent type & 6 \\
Cultivar & 15 \\
Seller & 27 & 5 \\
Retailer & 72 & 22.5 \\
Consumer/Buyer & & 60 \\
\hline
\end{tabular}

Number of respondents $(N=120)$.

TABLE 2: General awareness and sanitary conditions of vegetable cultivars, sellers, retailers, and consumers in Fitche town, Central Ethiopia, 2020 .

\begin{tabular}{|c|c|c|c|}
\hline Characteristics & Response & Frequency & Percent \\
\hline \multirow{2}{*}{ Information about contaminated vegetables can cause diseases to humans } & Yes & 102 & 85 \\
\hline & No & 18 & 15 \\
\hline \multirow{2}{*}{ Health problems occurred due to consuming contaminated vegetables } & Yes & 78 & 65 \\
\hline & No & 42 & 35 \\
\hline \multirow{5}{*}{ Transportation of fresh vegetables to reach the market } & Humans & 30 & 25 \\
\hline & Donkey/Horse & 12 & 10 \\
\hline & Cart & 24 & 20 \\
\hline & Car & 54 & 45 \\
\hline & $\mathrm{Sac}$ & 64 & 53 \\
\hline \multirow[t]{2}{*}{ Transporting containers } & Plastic bags & 18 & 15 \\
\hline & Boxes & 36 & 30 \\
\hline \multirow{2}{*}{ Organization of vegetables in the market without close contact } & Yes & 67 & 56 \\
\hline & No & 53 & 44 \\
\hline \multirow{2}{*}{ Using shade to protect vegetables from physical and solar damage } & Yes & 69 & 57.5 \\
\hline & No & 51 & 42.5 \\
\hline \multirow{5}{*}{ Time takes fresh vegetables left with seller/retailer before totally sold to the consumer } & $<1$ day & 36 & 30 \\
\hline & 1 day & 21 & 17.5 \\
\hline & 2 days & 9 & 7.5 \\
\hline & 3 days & 48 & 40 \\
\hline & $>3$ days & 6 & 5 \\
\hline \multirow{2}{*}{ Addition of food-grade chemicals such as vinegar for raw consumed vegetables } & Yes & 60 & 50 \\
\hline & No & 60 & 50 \\
\hline \multirow{2}{*}{ Using a refrigerator to store fresh vegetables } & Yes & 54 & 45 \\
\hline & No & 66 & 55 \\
\hline
\end{tabular}

Number of respondents $(N=120)$.

cabbage $(6.3 \mathrm{CFU} / \mathrm{g})$ and the lowest from tomato $(2.8 \mathrm{log}$ CFU/g). A study conducted by Guchi and Ashenafi [33] at Addis Ababa and a study from Morocco [34] reported a higher Enterobacteriaceae count ( $>4 \log \mathrm{CFU} / \mathrm{g}$ ) in lettuce and green pepper. Abadias et al. [35] recorded almost $79 \%$ of contamination in the samples with Enterobacteriaceae counts $(<5 \log \mathrm{CFU} / \mathrm{g})$. However, our study showed only $65 \%$ of Enterobacteriaceae count with $<5 \mathrm{log} \mathrm{CFU} / \mathrm{g}$. Coliforms were also detected from $2.1 \mathrm{log} \mathrm{CFU} / \mathrm{g}$ (tomato) to
$5.9 \log \mathrm{CFU} / \mathrm{g}$ (cabbage). In Zambia [36], coliforms ranged between 2.2 and $5.9 \log \mathrm{CFU} / \mathrm{g}$. A study from Saudi Arabia [28] reported that the coliform counts of salad were from 4.3 to $4.9 \log \mathrm{CFU} / \mathrm{g}$. Aycicek et al. [32] also found coliforms from 3.0 to $6.9 \log 10 \mathrm{CFU} / \mathrm{g}$. Total coliform presence may indicate contamination of vegetables from irrigation water, animal waste, sewage, soil, and feces [37]. Based on the findings of this study, higher counts of Enterobacteriaceae and coliform in cabbage and other vegetable samples are 


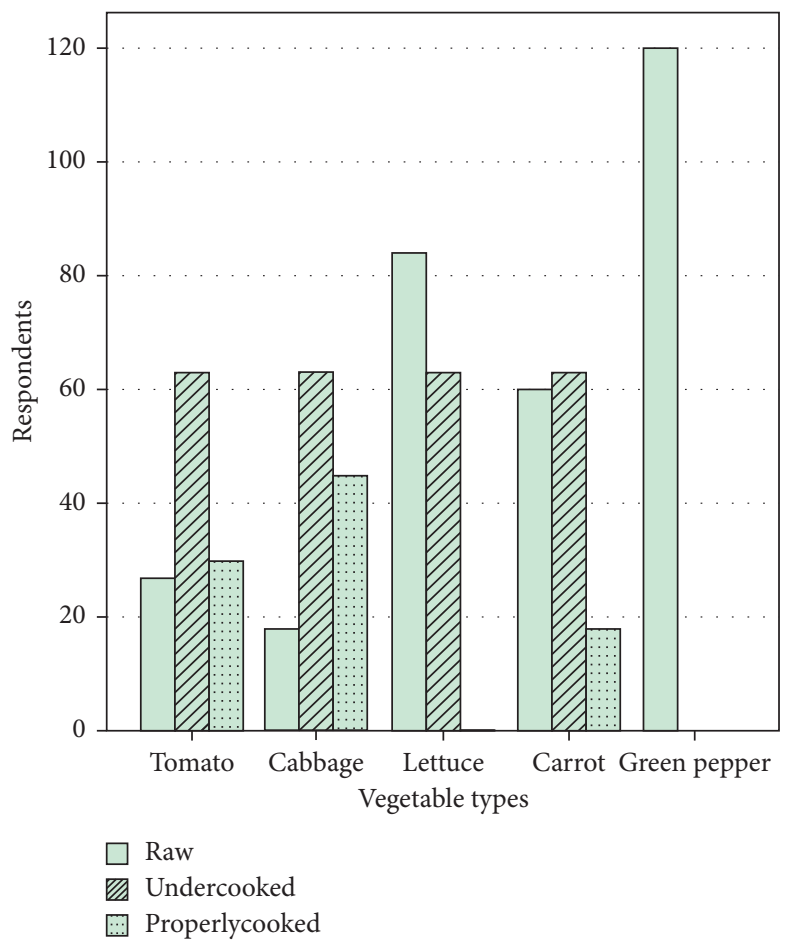

FIgURE 1: Frequently consumed vegetables in Fitche town, Central Ethiopia, 2020.

TABLe 3: Microbial counts (log CFU/g) of selected vegetables collected from markets in Fiche town, Central Ethiopia, 2020.

\begin{tabular}{|c|c|c|c|c|c|c|}
\hline \multirow{2}{*}{ Vegetable types } & \multicolumn{6}{|c|}{ Microbial groups $\log *$ CFU/g (mean \pm standard error) } \\
\hline & $\mathrm{AMB}^{\dagger}$ & $\mathrm{EB}^{\ddagger}$ & Coliforms & Staph $^{\S}$ & Yeast & Mold \\
\hline Tomato & $5.7 \pm 0.3$ & $3.7 \pm 0.5$ & $2.8 \pm 0.5$ & $2.5 \pm 0.2$ & $2.3 \pm 0.3$ & $2.2 \pm 0.4$ \\
\hline Cabbage & $6.4 \pm 0.6$ & $5.7 \pm 0.3$ & $5.1 \pm 0.5$ & $5.3 \pm 0.4$ & $2.4 \pm 0.3$ & $2.2 \pm 0.3$ \\
\hline Green pepper & $4.7 \pm 0.6$ & $4.7 \pm 0.5$ & $3.4 \pm 0.5$ & $3.7 \pm 0.2$ & $2.1 \pm 0.3$ & $1.7 \pm 0.3$ \\
\hline Carrot & $6.2 \pm 0.7$ & $4.2 \pm 0.5$ & $3.5 \pm 0.4$ & $3.3 \pm 0.4$ & $2.2 \pm 0.2$ & $1.8 \pm 0.3$ \\
\hline Lettuce & $5.3 \pm 0.7$ & $5.2 \pm 0.8$ & $4.3 \pm 0.7$ & $4.0 \pm 0.5$ & $2.5 \pm 0.3$ & $2.0 \pm 0.3$ \\
\hline Mean $(N=100)$ & $5.7 \pm 0.6$ & $4.7 \pm 0.5$ & $3.8 \pm 0.5$ & $3.8 \pm 0.3$ & $2.3 \pm 0.3$ & $2.0 \pm 0.3$ \\
\hline
\end{tabular}

${ }^{\dagger}$ Aerobic mesophilic bacteria, ${ }^{*}$ Enterobacteriaceae, ${ }^{\S}$ Staphylococci, and $*$ a colony forming unit.

attributed to poor hygiene practices of vegetables during harvesting. Furthermore, the impact of animal manure, unclean storerooms, unsuitable marketplaces, animal transportation, and wastewater irrigation should never be underestimated.

A high count of Staphylococci (4-6.9 log CFU/g) was recorded in cabbage and low (2.0-3.9 log CFU/g) in green pepper and tomato samples. Staphylococcus counts between 4.0 and $6.0 \log \mathrm{CFU} / \mathrm{g}$ [33] were reported in about $80 \%$ samples of green pepper and lettuce. Eni et al. [38] showed that $S$. aureus is frequent contamination from vegetables. It has been reported that the production of enterotoxin occurs when the counts of Staphylococcus aureus reach $6 \log \mathrm{CFU} / \mathrm{g}$ [39]. Staphylococcus aureus might occur on the vegetables' surface through contact from unwashed hands during choosing of vegetables to buy [40]. The observed mean counts of yeasts and molds were $\leq 2.9 \mathrm{log} \mathrm{CFU} / \mathrm{g}$ in the current study of all of the vegetable samples (100\%). Moreover, this study indicated that $55 \%$ of vegetable samples showed yeast and mold counts below the detectable level. Similar to our results, Dugassa et al. [4] showed that the counts of yeasts and molds in carrot and tomato were undetectable. Mritunjay and Kumar [29] recorded that yeast and mold counts range from 0.3 to $5.5 \mathrm{log} \mathrm{cfu} / \mathrm{g}$. Abadias et al. [35] and Tournas [41] obtained similar results with samples of fresh and minimally processed vegetables. In contrast to the present study, Seow et al. [42] isolated more yeast and mold counts from tomatoes as compared to the bacterial count. Some molds can produce mycotoxins and allergens, and large numbers of conidia may induce health instability [41, 43].

The presence of $S$. aureus in vegetables is dangerous to consumers. For instance, Salmonella spp. is associated with humans' gastrointestinal disorders, fever, abdominal cramp, vomiting, and diarrhea due to food poisoning [44]. Vegetables may get contaminated through improper handling [45] and from other environmental factors. A study conducted in Arba Minch Town, southern Ethiopia also 


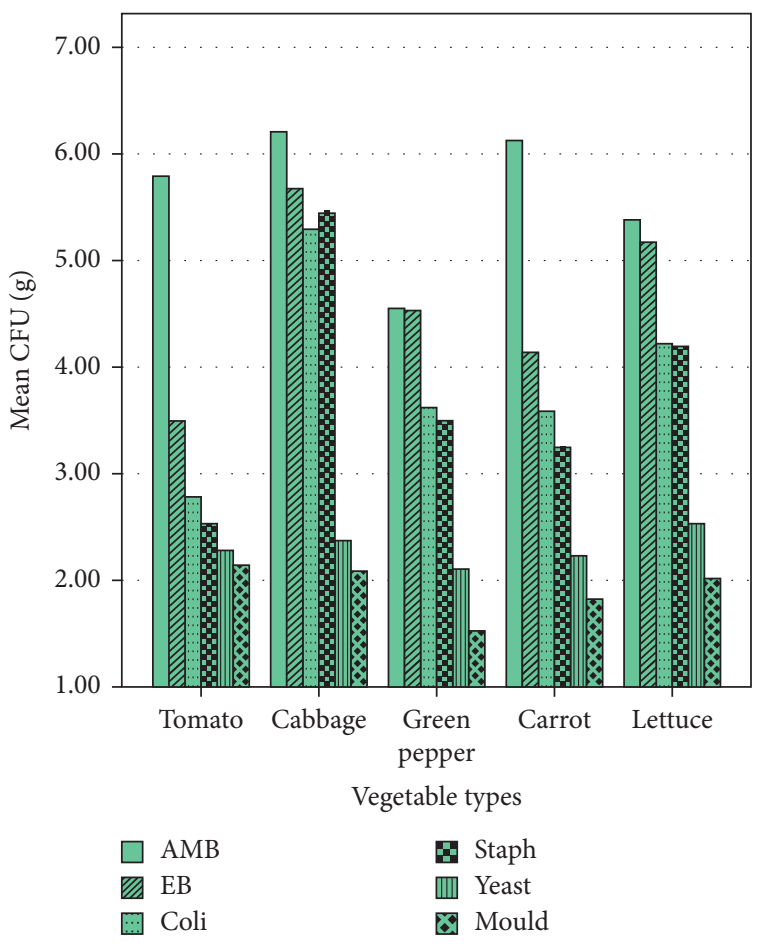

Figure 2: Microbiological count of raw vegetables collected from Komando site, Fitche town, Central Ethiopia, 2020.

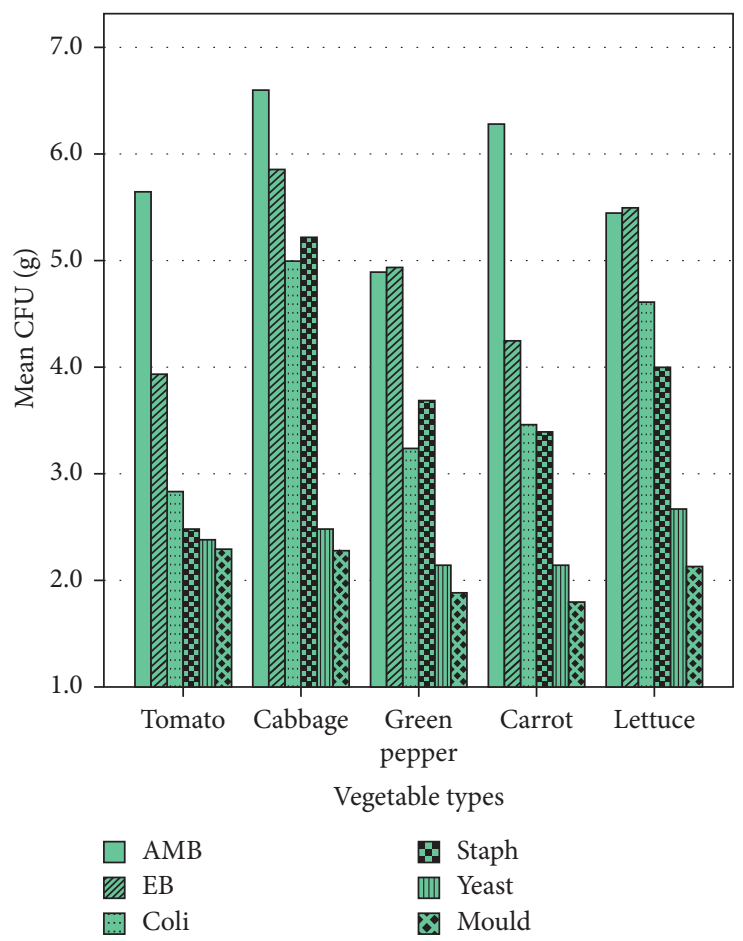

Figure 3: Microbiological count of raw vegetables collected from Fitche site, Fitche town, Central Ethiopia, 2020.

reported that less hygienically handled vegetables which are usually consumed in raw served to transmit various infectious diseases $[27,44]$. Therefore, cleaning using disinfectants should be practiced to make the vegetables fit for consumption in raw form.
In the present study, $25 \%$ of lettuce samples were found contaminated with Salmonella spp. [57] reported from Jimma city that $20.7 \%$ of the samples were positive for Salmonella. Another study conducted in the same city by Dugassa et al. (give year of publication) revealed that $16.7 \%$ 
TABle 4: Frequency distribution of tested microbes of selected vegetables sold in Fitche town, Central Ethiopia, 2020.

\begin{tabular}{|c|c|c|c|c|c|c|c|c|}
\hline \multirow{2}{*}{ Microbial groups } & \multirow{2}{*}{ Sample type } & \multicolumn{7}{|c|}{ * Log CFU/g (\%) } \\
\hline & & $<2$ & $2-2.9$ & $3-3.9$ & $4-4.9$ & $5-5.9$ & $6-6.9$ & $7-7.9$ \\
\hline \multirow{5}{*}{$\mathrm{AMB}^{\dagger}$} & Tomato & - & - & - & & $17(85)$ & $3(15)$ & \\
\hline & Cabbage & & & & $2(10)$ & $4(20)$ & $11(55)$ & $3(15)$ \\
\hline & Green pepper & - & - & $2(10)$ & $13(65)$ & $5(25)$ & - & - \\
\hline & Carrot & - & - & - & $2(10)$ & $4(20)$ & $14(70)$ & - \\
\hline & Lettuce & - & - & - & $4(20)$ & $13(65)$ & $3(15)$ & - \\
\hline \multirow{5}{*}{$\mathrm{EB}^{\ddagger}$} & Tomato & - & $1(5)$ & $15(75)$ & $4(20)$ & - & - & - \\
\hline & Cabbage & - & - & - & - & $17(85)$ & $3(15)$ & - \\
\hline & Green pepper & - & - & $3(15)$ & $11(55)$ & $6(30)$ & - & - \\
\hline & Carrot & - & - & $9(45)$ & $10(50)$ & $1(5)$ & - & - \\
\hline & Lettuce & - & - & - & $8(40)$ & $7(35)$ & $5(25)$ & - \\
\hline \multirow{5}{*}{ Coliforms } & Tomato & - & $12(60)$ & $8(40)$ & - & - & - & - \\
\hline & Cabbage & - & - & - & $6(30)$ & $14(70)$ & - & - \\
\hline & Green pepper & - & $4(20)$ & $15(75)$ & $1(5)$ & - & - & - \\
\hline & Carrot & - & $2(10)$ & $16(80)$ & $2(10)$ & - & - & - \\
\hline & Lettuce & - & - & $3(30)$ & $13(65)$ & $4(20)$ & - & - \\
\hline \multirow{5}{*}{$\operatorname{Staph}^{\S}$} & Tomato & - & $20(100)$ & - & - & - & - & - \\
\hline & Cabbage & - & - & - & $3(15)$ & $16(80)$ & $1(5)$ & - \\
\hline & Green pepper & - & - & $20(100)$ & - & - & - & - \\
\hline & Carrot & - & $2(10)$ & $16(80)$ & $2(10)$ & - & - & - \\
\hline & Lettuce & - & - & $8(40)$ & $12(60)$ & - & - & - \\
\hline \multirow{5}{*}{ Yeasts } & Tomato & $4(20)$ & $16(80)$ & - & - & - & - & - \\
\hline & Cabbage & $1(5)$ & $18(90)$ & $1(5)$ & - & - & - & - \\
\hline & Green pepper & $5(25)$ & $15(75)$ & - & - & - & - & - \\
\hline & Carrot & $4(20)$ & $16(80)$ & - & - & - & - & - \\
\hline & Lettuce & - & $20(100)$ & - & - & - & - & - \\
\hline \multirow{2}{*}{ Mold } & Tomato & $4(20)$ & $16(80)$ & - & - & - & - & - \\
\hline & Cabbage & $4(20)$ & $16(80)$ & - & - & - & - & - \\
\hline
\end{tabular}

${ }^{\dagger}$ Aerobic mesophilic bacteria, ${ }^{\ddagger}$ Enterobacteriaceae, ${ }^{\S}$ Staphylococci, and $*$ a colony forming unit.

TABLE 5: Frequency of isolation of S. aureus, Salmonella spp, and Shigella spp of some vegetables sold in Fitche town, Central Ethiopia, 2020.

\begin{tabular}{lccc}
\hline Vegetable types & Sample size (100) & No. of S. Aureus (\%) & No. of Salmonella spp. (\%) \\
\hline Tomato & 20 & 10.0 & 20.0 \\
Cabbage & 20 & 20.0 & 20.0 \\
Green pepper & 20 & 5.0 & 5.0 \\
Carrot & 20 & 0.0 & 5.0 \\
Lettuce & 20 & 15.0 & 25.0 \\
Total & 100 & 11.0 & 15.0 \\
\hline
\end{tabular}

of the lettuce samples have been contaminated with Salmonella spp. Rajkowski and Fan [45] reported that Salmonella spp. was prevalent particularly from lettuce samples. Folded foliar surfaces of lettuce leaves may have contributed by making a conducive surface for bacterial growth [32, 49, 50]. Kumar [51] and Singh et al. [52] found that vegetables generally harbor Salmonella spp. Singh et al. [52] also indicated that stagnant water used for sprinkling and cleaning vegetables might be the most important way of contaminating vegetables with Salmonella spp. This report is in confirmation with the finding from the Middle East which detected $6.7 \%$ of the raw vegetables from the postharvest, washing areas of Bekaa Valley, Lebanon, and Beirut [53]. In addition, producing vegetables by using manure, using contaminated water for irrigation might have significantly contributed to the contamination [38]. The presence of Salmonella, above the recommended limit, could pose a serious threat to the health of consumers and is regarded unacceptable for consumption [54]. To control the contamination of vegetables by microbial pathogens, different techniques such as disinfection $[55,56]$, modified atmospheric conditions, refrigeration, and innovative technologies need to be exploited before consumption [6] because thorough washing was not reportedly sufficient to reduce pathogen levels to safer limits in leafy vegetable types studied [57].

\section{Conclusion}

In the current study, out of five vegetable types analyzed, cabbage samples were contaminated with high microbial load followed by carrot. Prevalence of Salmonella and Staphylococcus aureus in cabbage than the other vegetable samples indicate the poor sanitary condition and improper 
handling at both harvesting and marketing. Detection of pathogens from vegetables necessitates the adoption of best agricultural and handling practices by farmers, and good hygienic practices of food vendors, processors, and consumers are required to minimize the risks of transmission of pathogens. The possible causes of preharvesting and postharvesting contamination of vegetables might be due to their production on contaminated soil and washing of the vegetable with wastewater. The results of the present study, especially the identification of microorganisms, are also useful to the clinicians for treating the patients with the right kind of medicines. Farmers should be informed about the sources of microbial contamination. Furthermore, the government may have a close observation of the pre and postharvesting activities of vegetable producers and sellers to minimize the risk of diseases. Fresh vegetables should be protected from contamination by humans, animals, and other wastes which may constitute a hazard to the health of the consumer through fresh produces. Moreover, it is recommended to avoid consuming raw vegetables without adding food-grade chemicals (antimicrobial agents) which reduce microbial load.

\section{Data Availability}

The data used to support the findings of this study are included within the article.

\section{Conflicts of Interest}

The authors declare no potential conflicts of interest.

\section{Acknowledgments}

This research was fully funded by Salale University. Research and publication directorate is acknowledged for approving the necessary budget. The appreciation is also extended to Salale University for funding the research and Wolkite University for the provision of laboratory facilities. The cost of the research has been covered by Salale University.

\section{References}

[1] E. M. Yahia, P. García-Solís, and M. E. M. Celis, "Contribution of fruits and vegetables to human nutrition and health," in Postharvest Physiology and Biochemistry of Fruits and Vegetables, pp. 19-45, Woodhead Publishing, Sawston, UK, 2019.

[2] E. Radziejewska-Kubzdela, J. Czapski, K. Czaczyk, and R. Biegańska-Marecik, "The effect of pre-treatment and modified atmosphere packaging on contents of phenolic compounds and sensory and microbiological quality of shredded celeriac," Journal of the Science of Food and Agriculture, vol. 94, no. 6, pp. 1140-1148, 2014.

[3] A. Septembre-Malaterre, F. Remize, and P. Poucheret, "Fruits and vegetables, as a source of nutritional compounds and phytochemicals: changes in bioactive compounds during lactic fermentation," Food Research International, vol. 104, pp. 86-99, 2018.

[4] A. Dugassa, K. Bacha, and T. Ketama, "Microbiological quality and safety of some selected vegetables sold in Jimma town, Southwestern Ethiopia," African Journal of Environmental Science and Technology, vol. 8, no. 11, pp. 633-653, 2014.

[5] L. R. Beuchat, "Ecological factors influencing survival and growth of human pathogens on raw fruits and vegetables," Microbes and Infection, vol. 4, no. 4, pp. 413-423, 2002.

[6] S. A. Mir, M. A. Shah, M. M. Mir, B. N. Dar, R. Greiner, and S. Roohinejad, "Microbiological contamination of ready-toeat vegetable salads in developing countries and potential solutions in the supply chain to control microbial pathogens," Food Control, vol. 85, pp. 235-244, 2018.

[7] T. P. Ramees, K. Dhama, K. Karthik et al., "Arcobacter: an emerging food-borne zoonotic pathogen, its public health concerns and advances in diagnosis and control - a comprehensive review," Veterinary Quarterly, vol. 37, no. 1, pp. 136-161, 2017.

[8] F. Yeni, S. Yavaş, H. A. M. I. Alpas, and Y. E. S. I. M Soyer, "Most common foodborne pathogens and mycotoxins on fresh produce: a review of recent outbreaks," Critical Reviews in Food Science and Nutrition, vol. 56, no. 9, pp. 1532-1544, 2016.

[9] M. A. Halablab, I. H. Sheet, and H. M. Holail, "Microbiological quality of raw vegetables grown in Bekaa Valley, Lebanon," American Journal of Food Technology, vol. 6, no. 2, pp. 129-139, 2011.

[10] A. M. Al-Binali, C. S. Bello, K. El-Shewy, and S. E. Abdulla, "The prevalence of parasites in commonly used leafy vegetables in South Western, Saudi Arabia," Saudi Medical Journal, vol. 27, no. 5, pp. 613-616, 2006.

[11] O. O. Alegbeleye, I. Singleton, and A. S. Sant'Ana, "Sources and contamination routes of microbial pathogens to fresh produce during field cultivation: a review," Food Microbiology, vol. 73, pp. 177-208, 2018.

[12] A. Allende, M. V. Selma, F. López-Gálvez, R. Villaescusa, and M. I. Gil, "Role of commercial sanitizers and washing systems on epiphytic microorganisms and sensory quality of fresh-cut escarole and lettuce," Postharvest Biology and Technology, vol. 49, no. 1, pp. 155-163, 2008.

[13] Y. Wadamori, R. Gooneratne, and M. A. Hussain, "Outbreaks and factors influencing microbiological contamination of fresh produce," Journal of the Science of Food and Agriculture, vol. 97, no. 5, pp. 1396-1403, 2017.

[14] H. Ayçiçek, H. Aydoğan, A. Küçükkaraaslan, M. Baysallar, and A. C. Başustaoğlu, "Assessment of the bacterial contamination on hands of hospital food handlers," Food Control, vol. 15, no. 4, pp. 253-259, 2004.

[15] M. Chaturvedi, V. Kumar, D. Singh, and S. Kumar, "Assessment of microbial load of some common vegetables among two different socioeconomic groups," International Food Research Journal, vol. 20, no. 5, p. 2927, 2013.

[16] V. Lievin, I. Peiffer, S. Hudault et al., "Bifidobacterium strains from resident infant human gastrointestinal microflora exert antimicrobial activity," Gut, vol. 47, no. 5, pp. 646-652, 2000.

[17] J. N. Ssemanda, M. W. Reij, G. van Middendorp et al., "Foodborne pathogens and their risk exposure factors associated with farm vegetables in Rwanda," Food Control, vol. 89, pp. 86-96, 2018.

[18] G. I. Balali, D. D. Yar, V. G. Afua Dela, and P. Adjei-Kusi, "Microbial contamination, an increasing threat to the consumption of fresh fruits and vegetables in today's world," International Journal of Microbiology, vol. 2020, Article ID 3029295, 13 pages, 2020. 
[19] A. N. Olaimat and R. A. Holley, "Factors influencing the microbial safety of fresh produce: a review," Food Microbiology, vol. 32, no. 1, pp. 1-19, 2012.

[20] S. Kemal Buyukunal, G. Issa, F. Aksu, and A. Vural, "Microbiological quality of fresh vegetables and fruits collected from supermarkets in Istanbul, Turkey," Journal of Food and Nutrition Sciences, vol. 3, no. 4, pp. 152-159, 2015.

[21] S. Shalini, Study on Microbiological Aspects of Fresh Fruit and Vegetables (Including Green Leafy Vegetables) in and Around National Capital Region (NCR), Bhaskaracharya College of Applied Sciences, Dwarka, India, 2010.

[22] J. F. Spencer and A. L. R. de Spencer, Food Microbiology Protocols, Vol. 14, Springer Science \& Business Media, Berlin, Germany, 2001.

[23] M. Acco, F. S. Ferreira, J. A. P. Henriques, and E. C. Tondo, "Identification of multiple strains of Staphylococcus aureus colonizing nasal mucosa of food handlers," Food Microbiology, vol. 20, no. 5, pp. 489-493, 2003.

[24] J. O. Orji, C. Orinya, E. Okonkwo et al., "The microbial contamination of ready-to-eat vended fruits in abakpa main market, abakaliki, ebonyi state, Nigeria," Journal of Pharmaceutical and Biological Sciences, vol. 11, pp. 71-80, 2016.

[25] B. Keraita, R. Abaidoo, I. Beernaerts et al., "Safe re-use practices in wastewater-irrigated urban vegetable farming in Ghana," Journal of Agriculture, Food Systems, and Community Development, vol. 2, no. 4, pp. 147-158, 2012.

[26] B. Ray and A. Bhunia, "Important facts in foodborne diseases," Fundamental Food Microbiology, CRC Press, Boca Raton, FL, USA, 2007.

[27] A. N. Tong Thi, P. Kittirath, S. D. Abiola, and L. N. Doan Duy, "Evaluation of street food safety and hygiene practices of food vendors in can tho city of vietnam," Current Research in Nutrition and Food Science Journal, vol. 9, no. 1, pp. 158-171, 2021.

[28] M. Khiyami, A. F. Noura, B. Busaeed, and H. Sher, "Food borne pathogen contamination in minimally processed vegetable salads in Riyadh, Saudi Arabia," Journal of Medicinal Plants Research, vol. 5, no. 3, pp. 444-451, 2011.

[29] S. K. Mritunjay and V. Kumar, "A study on prevalence of microbial contamination on the surface of raw salad vegetables," 3 Biotech, vol. 7, no. 1, p. 13, 2017.

[30] G. J. Tortora, B. R. Funke, and C. Case, Microbiology: An Introduction, Benjamin-Cummings, Redwood City, CA, USA, 1995.

[31] T. Bintsis, "Microbial pollution and food safety," AIMS Microbiology, vol. 4, no. 3, pp. 377-396, 2018.

[32] H. Aycicek, U. Oguz, and K. Karci, "Determination of total aerobic and indicator bacteria on some raw eaten vegetables from wholesalers in Ankara, Turkey," International Journal of Hygiene and Environmental Health, vol. 209, no. 2, pp. 197201, 2006.

[33] B. Guchi and M. Ashenafi, "Microbial load, prevalence and antibiograms of Salmonella and Shigella in lettuce and green peppers," Ethiopian Journal of Health Sciences, vol. 20, no. 1, pp. 41-48, 2010.

[34] K. Ibenyassine, R. A. Mhand, Y. Karamoko, B. Anajjar, M. M. Chouibani, and M. Ennaji, "Bacterial pathogens recovered from vegetables irrigated by wastewater in Morocco," Journal of Environmental Health, vol. 69, no. 10, pp. 47-51, 2007.

[35] M. Abadias, J. Usall, M. Anguera, C. Solsona, and I. Viñas, "Microbiological quality of fresh, minimally-processed fruit and vegetables, and sprouts from retail establishments,"
International Journal of Food Microbiology, vol. 123, no. 1-2, pp. 121-129, 2008.

[36] K. Nguz, J. Shindano, S. Samapundo, and A. Huyghebaert, "Microbiological evaluation of fresh-cut organic vegetables produced in Zambia," Food Control, vol. 16, no. 7, pp. 623-628, 2005.

[37] A. J. Hamilton, F. Stagnitti, R. Premier, A.-M. Boland, and G. Hale, "Quantitative microbial risk assessment models for consumption of raw vegetables irrigated with reclaimed water," Applied and Environmental Microbiology, vol. 72, no. 5, pp. 3284-3290, 2006.

[38] A. O. Eni, I. A. Oluwawemitan, and O. U. Solomon, "Microbial quality of fruits and vegetables sold in Sango Ota, Nigeria," African Journal of Food Science, vol. 4, no. 5, pp. 291-296, 2010.

[39] J. Schelin, N. Wallin-Carlquist, M. Thorup Cohn, R. Lindqvist, and G. C. Barker, "The formation ofStaphylococcus aureusenterotoxin in food environments and advances in risk assessment," Virulence, vol. 2, no. 6, pp. 580-592, 2011.

[40] O. Iyoha and F. Agoreyo, "Bacterial contamination of ready to eat fruits sold in and around Ugbowo campus of University of Benin (Uniben), Edo State, Nigeria," British Journal of Medicine and Medical Research, vol. 7, no. 2, pp. 155-160, 2015.

[41] V. H. Tournas, "Moulds and yeasts in fresh and minimally processed vegetables, and sprouts," International Journal of Food Microbiology, vol. 99, no. 1, pp. 71-77, 2005.

[42] J. Seow, R. Ágoston, L. Phua, and H.-G. Yuk, "Microbiological quality of fresh vegetables and fruits sold in Singapore," Food Control, vol. 25, no. 1, pp. 39-44, 2012.

[43] Y.-H. Seo, J.-H. Jang, and K.-D. Moon, "Microbial evaluation of minimally processed vegetables and sprouts produced in Seoul, Korea," Food Science and Biotechnology, vol. 19, no. 5, pp. 1283-1288, 2010.

[44] E. O. Erhirhie, M. A. Omoirri, S. C. Chikodiri, T. N. Ujam, K. E. Emmanuel, and J. O. Oseyomon, "Microbial quality of fruits and vegetables in Nigeria: a," International Journal of Nutrition Sciences, vol. 5, no. 3, pp. 2-11, 2020.

[45] R. Wills and J. Golding, Postharvest: An Introduction to the Physiology and Handling of Fruit and Vegetables, UNSW Press, Kensington, Australia, 2016.

[46] D. Weldezgina and D. Muleta, "Bacteriological contaminants of some fresh vegetables irrigated with awetu river in Jimma town, southwestern Ethiopia," Advances in Biology, vol. 201611 pages, Article ID 1526764, 2016.

[47] G. Alemu, M. Mama, and M. Siraj, "Bacterial contamination of vegetables sold in Arba Minch town, Southern Ethiopia," BMC Research Notes, vol. 11, no. 1, pp. 775-5, 2018.

[48] K. T. Rajkowski and X. Fan, "Microbial quality of fresh-cut iceberg lettuce washed in warm or cold water and irradiated in a modified atmosphere package," Journal of Food Safety, vol. 28, no. 2, pp. 248-260, 2008.

[49] E. Franz, S. O. Tromp, H. Rijgersberg, and H. J. Van Der FelsKlerx, "Quantitative microbial risk assessment for Escherichia coli O157:H7, Salmonella, and Listeria monocytogenes in leafy green vegetables consumed at salad bars," Journal of Food Protection, vol. 73, no. 2, pp. 274-285, 2010.

[50] Y. H. Zwe and H. G. Yuk, "Food quality and safety in Singapore: microbiology aspects," Food Quality and Safety, vol. 1, no. 2, pp. 101-105, 2017.

[51] V. Kumar, "Incidence of Salmonella sp. and Listeria monocytogenes in some salad vegetables, which are eaten raw: a study of Dhanbad City, India," International Journal of Engineering Science, vol. 2, no. 10, pp. 1437-1442, 2012. 
[52] B. R. Singh, P. Singh, A. Verma et al., "A study on prevalence of multi-drug-resistant (MDR) Salmonella in water sprinkled on fresh vegetables in Bareilly, Moradabad, and Kanpur (northern Indian cities)," Journal of Public Health, vol. 14, no. 3, pp. 125-131, 2006.

[53] D. Faour-Klingbeil, M. Murtada, V. Kuri, and E. C. D. Todd, "Understanding the routes of contamination of ready-to-eat vegetables in the Middle East," Food Control, vol. 62, pp. 125-133, 2016.

[54] P.-Y. Cheung, K. K. Kwok, and K. M. Kam, “Application of BAX system, tecra unique TM Salmonella test, and a conventional culture method for the detection of Salmonella in ready-to-eat and raw foods," Journal of Applied Microbiology, vol. 103, no. 1, pp. 219-227, 2007.

[55] D. Nei, K. Enomoto, and N. Nakamura, "A gaseous acetic acid treatment to disinfect fenugreek seeds and black pepper inoculated with pathogenic and spoilage bacteria," Food Microbiology, vol. 49, pp. 226-230, 2015.

[56] S.-H. Sun, S.-J. Kim, S.-J. Kwak, and K.-S. Yoon, "Efficacy of sodium hypochlorite and acidified sodium chlorite in preventing browning and microbial growth on fresh-cut produce," Preventive Nutrition and Food Science, vol. 17, no. 3, pp. 210-216, 2012.

[57] G. D. D. De Silva, C. L. Abayasekara, and D. R. A. Dissanayake, "Freshly eaten leafy vegetables: a source of food borne pathogens?" Ceylon Journal of Science (Bio. Sci.), vol. 42, no. 2, pp. 95-99, 2013. 